
17. SIGNATURE/DISTRIBUTION

(See Approval Designator for required signatures)

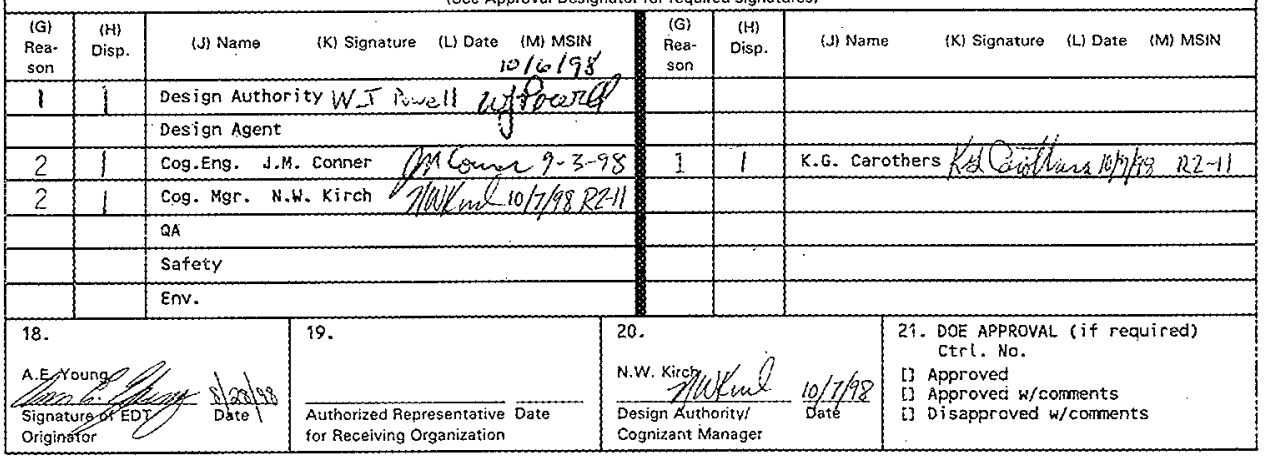




\section{Contingency Plan for Deployment of the Void Fraction Instrument in Tank 241-AY-102}

John M. Conner

Lockheed Mart in Hanford, Corp. , Richland. WA 99352

U.S. Department of Energy Contract DE-AC06-96RL13200

EDT/ECN: EDT-622465 UC: 2070

Org Code: 7A150 Charge Code: D2M78

BQR Code: EW 3120074 Total Pages: 15

Key Words: Contingency Plan, Plan, Deployment, Void Fraction Instrument, Tank 241-AY-102, Tank AY-102, AY-102, AY Farm

Abstract: N/A

TRADEMARK DISCLAIMER. Reference herein to any specific comercial product, process, or service by trade name, trademark, manufacturer, or otherwise, does not necessarily constitute or imply its endorsement, recommendation, or favoring by the United States Governnent or any agency thereof or its contractors or subcontractors.

Printed in the United States of America. To obtain copies of this document, contact: Document Control Services, P.0. Box 950, Mailstop H6-08, Richland WA 99352, Phone (509) 372-2420; Fax (509) 376-4989.

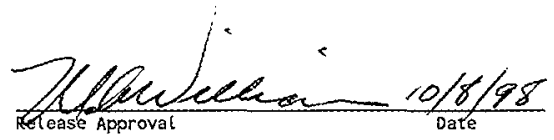

\section{Approved for Public Release}




\section{Contingency Plan for Deployment of Void Fraction Instrument in Tank 241-AY-102}

\section{Introduction}

High-heat producing sludge from tank $241-\mathrm{C}-106$ will be sluiced and transferred to tank 241-AY-102 beginning in October 1998. Safety analyses have postulated that after retrieval, the waste in 241-AY-102 may generate and retain unsafe levels of flammable gases (Noorani 1998, Pasamehmetoglu et al. 1997). Unsafe levels of retained gas are not expected, but cannot be ruled out because of the large uncertainty in the gas generation and retention rates. The Tank Waste Remediation System Basis for Interim Operation (Noorani 1998) identifies the need for a contingency plan to add void fraction monitoring to tank 241-AY-102 within 2 weeks of the identification of flammable gas buildup that would warrant monitoring. The Tank 241-C-106 Waste Retrieval Sluicing System Process Control Plan (Carothers et al. 1998) committed to providing a contingency plan for deployment of the void fraction instrument (VFI) in tank 241-AY-102.

The VFI determines the local void fraction of the waste by compressing a waste sample captured in a gas-tight test chamber. The sample chamber is mounted on the end of a $76-\mathrm{cm}(2.5-\mathrm{ft})$ arm that can be rotated from vertical to horizontal when the instrument is deployed. Once in the waste, the arm can be positioned horizontally and rotated to sample in different areas below the riser. The VFI is deployed using a crane. The VFI has been deployed previously in 241-AW, 241-AN, and 241-SY tank farms, most recently in tank 241-SY-101 in June and July 1998. An additional test in tank 241-SY101 is planned in September 1998. Operating instructions for the VFI are included in the Void Fraction Instrument Operation and Maintenance Manual (Pearce 1994).

\section{Scope}

This document lists the documentation and resources required and provides an estimated schedule for rapid deployment of the VFI in tank 241-AY-102. The VFI will be deployed to verify the quantity of flammable gas retained by the waste if a high void fraction develops in the settled sludge.

\section{VEI Deployment Steps}

The steps necessary to deploy the VFI in tank 241-AY-102 are listed below. The steps are broken down into three categories: documentation, field work, and reporting. Appendix A consists of an estimated schedule to carry out the tasks, and also includes a resource breakdown. 


\section{Documentation}

Decision to deploy VFI. The decision to deploy the VFI would be made by the Tank 241-C-106 Waste Retrieval Technical Review Group (TRG). The TRG is comprised of people from various organizations including operations, safety and licensing, safety oversight, design authority, process engineering, technical experts, and the shuicing system cognizant engineer (LMHC 1998a). The 241-C-106 Sluicing Operations Manager, G. N. Hanson, chairs the TRG. The TRG will meet weekly once sluicing operations begin, although meetings could be arranged at another time under special circumstances.

Riser selection. Risers ate typically selected by reviewing riser documents such as Waste Tank Risers Available for Sampling (Lipnicki 1997) and then performing a field walkdown to verify that the riser is accessible. Riser $15 \mathrm{I}$ has already been chosen for deployment of the VFI.

Dome loading letter. A baseline dome loading for the tank has already been calculated. The calculation to document that deployment of the VFI and its associated support skids will not exceed allowable limits has been drafted and included in the work package (LMHC 1998b). The calculation cannot be finalized until deployment nears because the equipment load might change.

Critical lift procedure. A job-specific critical lift procedure is required for the deployment of the VFI via a crane. The procedure for this activity has been completed and included in the work package (LMHC 1998b).

HiLine Engineering support contract. HiLine Engineering \& Fabrication, Inc., of Richland, Washington, fabricated the VFI device and is the regional representative of the software manufacturer. HiLine has provided technical support during past VFI deployments on an as-needed basis (hourly rate) through a contract that will expire at the end of fiscal year 1998. This contract needs to be extended or a contract placed for fiscal year 1999 .

Unreviewed Safety Question (USQ) determination for deployment. Deployment of the VFI is not covered by safety documentation, so a USQ screening (USQ TF-98-0-857) has been prepared (Ethart 1998). The USQ will be included in the work package.

Unreviewed Safety Question determination for compliance with the TWRS BIO. The TWRS BIO, Addendum 1, Section 2.5.2.3.8 (Noorani 1998) states that the VFI must be able to be deployed in 2 weeks. The schedule for deployment and reporting provided below runs longer than 2 weeks. A USQ determination has been prepared (Carlstrom 1998) to address this issue.

Update VFI deployment work package. A work package has already been written in anticipation of this activity (LMHC 1998b). The package includes the documentation 
listed above, along with the work instruction and other items such as the radiation work permit and job hazards analysis. Some modification of the package would be necessary prior to the job to include final documentation and update to the latest requirements and procedures, if necessary. J. D. Thorne of TWRS Production Control prepared the package.

Write VFI transportation work package. A work package for transporting the VFI apparatus and associated equipment will need to be written. A work package will also need to be written to cover transportation of the VFI and supporting equipment to a suitable storage location at the conclusion of VFI measurements. Since the VFI is deployed inside waste tanks, it is considered to be contaminated equipment.

Write VFI calibration work package. A work package to calibrate the VFI will need to be written. The previous calibration was conducted according to work package 2 W-98$00760 / \mathrm{W}$. Two supporting documents used to write the package were Void Fraction Instrument Calibration Requirements and Procedures (Gimera 1995a) and Void Fraction Instrument Calibration Report (Gimera 1995b).

Write VFI test plan. The test plan describes the strategy for data acquisition, depending on where the gas is expected to be in the waste. The plan lists the sample locations (riser, orientation of pivot arm, and elevation above tank bottom). The plan lists any operational and safety constraints, such as chamber pressurization limits and monitoring the crane load cell readout to ensure that neither the VFI nor the tank is damaged. J. M. Alzheimer of PNNL will write the test plan. An example of a previous test plan is Data Acquisition Plan for. Void Fraction Measurements in Tank 241-SY-101, Rev. D (Alzheimer 1998a).

Letter of Instruction (LOI) to deploy the VFI. The LOI is a memo from TWRS Process Engineering to the appropriate field operations manager directing deployment of the VFI. The LOI describes the test, references the test plan and programmatic drivers such as data quality objectives or process control plans, and states requirements such as deliverables and quality assurance and safety requirements. The "Letter of Instruction for Void Fraction Measurements in Tank 241-SY-101" (Wilkins 1998) is an example of a recent $L O I$.

\section{Field Activities}

Transport to AY Farm. The VFI is expected to remain at the 241-SY tank farm. If deployment in tank 241-AY-102 is necessary, the VFI and associated equipment will need to be transported to the 241-AY tank farm. The transportation would be covered by one of the transportation work packages discussed above.

Riser preparation. Riser preparation involves such things as removing the riser cap, sniffing for flammable gases, grounding the VFI to protect against lightning strikes, and 
bonding the VFI for static discharge. These activities are covered in the work package (LMHC 1998b).

Construct scaffolding. Scaffolding around the riser is required to provide access for operating the VFI. The work package (LMHC 1998b) directs the erection and inspection of the scaffolding, and references the appropriate procedures and inspection checklist.

Install VFI control console, power distribution skid, disconnect skid, weather enclosure, and water decontamination system. The VFI control console includes the computer used to operate the apparatus. The console and skids will be connected to available outlets in the tank farm. The water decontamination system will either be connected to an available outlet or to a water truck.

Install ball valve and spray washer. The ball valve seals off the tank until the VFI is ready to be deployed. The spray washer is used to decontaminate the cable and VFI as they are removed from the tank.

Install portable camera. A camera is required to zero the VFI at the waste surface level and also for performing decontamination. The camera is also useful to observe the waste surface for released gas bubbles during operation of the VFI. It is expected that riser $15 \mathrm{~A}$ will be used for the camera. The line of sight to riser $15 I$ where the VFI will be deployed may be partially obstructed by one of the 22-foot airlift circulators and its thermocouple well. Based on drawing $\mathrm{H}-2-64447$, the line of sight between the camera and riser $15 \mathrm{I}$ should pass 16 inches to the left of the 30 inch diameter airlift circulator pipe. Before installing the VFI, the line of sight will be verified to ensure that the selected riser is acceptable.

Calibrate VFI. Calibration consists of verifying the various temperature and pressure sensors and length measuring device of the VFI are working properly. Calibration will be performed according to the calibration work package described above.

Install VFI, operate, and remove. The VFI will be installed and operated in accordance with the work package (LMHC 1998b) and the operating manual (Pearce 1994).

Remove equipment, scaffolding, etc. and final cleanup. The equipment is removed and returned to storage. The VFI and associated equipment will be moved to a suitable storage location.

\section{Reporting}

Issue data report. A short data report will be written describing the test and presenting and discussing the data. An example of a VFI test report is the Void Fraction Instrument Data for SY-101, Riser 11-B, June 29 and July 22, 1998, Quick Look Report (Alzheimer 1998b). 


\section{Assumptions}

The following assumptions were made:

- The VFI is available and in good working order. If the VFI is broken during transport or use on other projects, rough estimates of the time and cost to build another are 1 year and $\$ 1$ million.

- Testing of the VFI software for compliance with year 2000 issues is completed prior to deployment. Year 2000 compliance testing is scheduled to be completed in March 1999, and VFI deployment is not anticipated until at least June 1999.

- A water lance is not needed since there is no crust in tank 241-AY-102.

- No new requirements (e.g. safety, operational, or oversight) will be required.

- No additional USQ discoveries are associated with the proposed tasks.

- The VFI would be deployed in 1999 or 2000.

- No weather or other unforeseen delays occur.

- The deployment would be given a high priority relative to other projects. Shift work and overtime will be used to expedite deployment of the VFI.

- Funding is available when the deployment decision is made.

\section{Schedule}

An estimated schedule is attached as Appendix A. The schedule is a reasonable estimate of the time required to prepare the necessary documentation, deploy the VFI, and report the results. The overall schedule estimate is as follows:

\begin{tabular}{ll} 
Documentation & 2.5 weeks \\
Field activities & 2 weeks \\
Reporting & 1 week \\
\hline Total & 5.5 weeks
\end{tabular}

It is possible that the activity could be accomplished in less time, possibly as little as 23 weeks to get results. However, as stated above, this is a more reasonable estimate. Much of the documentation has been prepared already. Additional work that could be done includes preparing the VFI transportation and calibration packages and ensuring that contractual arrangements with HiLine Engineering and PNNL are in place. 
Because this schedule does not meet the BIO commitment of a two-week deployment (Noorani 1998), a USQ has been prepared (Carlstrom 1998).

\section{Acknowledgments}

The following people assisted this effort by preparing supporting documentation providing estimates or comments.

\begin{tabular}{|c|c|c|}
\hline Person & Organization & Role \\
\hline $\begin{array}{l}\text { J. M. } \\
\text { Alzheimer }\end{array}$ & $\begin{array}{l}\text { PNNL Mechanical \& } \\
\text { Robotic Systems }\end{array}$ & Review of test plan and reporting estimates \\
\hline J. W. Bailey & Process Design & Review of document and USQ \\
\hline K. A. Baird & SST Field Ops & $\begin{array}{l}\text { Provided resource estimates for field } \\
\text { activities }\end{array}$ \\
\hline $\begin{array}{l}\text { R. F, } \\
\text { Carlstrom }\end{array}$ & SAR Engineering & $\begin{array}{l}\text { Preparation of USQ relating to BIO } \\
\text { requirement }\end{array}$ \\
\hline $\begin{array}{l}\text { K. G. } \\
\text { Carothers }\end{array}$ & TWRS Process Eng & Overall review \\
\hline M. F. Erhart & TWRS Equipment Eng & $\begin{array}{l}\text { Prepared USQ screening for deployment } \\
\text { reviewed document }\end{array}$ \\
\hline J. J. Kinzer & $\begin{array}{l}\text { TWRS Production } \\
\text { Control }\end{array}$ & $\begin{array}{l}\text { Provided information from calibration } \\
\text { procedures and } 241-S Y-101 \text { VFI work } \\
\text { package for review }\end{array}$ \\
\hline $\begin{array}{l}\text { D. L. } \\
\text { Macfarlan }\end{array}$ & $\begin{array}{l}\text { TWRS Production } \\
\text { Control }\end{array}$ & Prepared schedule and resource breakdown \\
\hline $\begin{array}{l}\text { R. S. } \\
\text { Rodriquez }\end{array}$ & $\begin{array}{l}\text { TWRS Production } \\
\text { Control }\end{array}$ & $\begin{array}{l}\text { Review of schedule and resource } \\
\text { breakdown }\end{array}$ \\
\hline J. D. Thorne & $\begin{array}{l}\text { TWRS Production } \\
\text { Control }\end{array}$ & $\begin{array}{l}\text { Preparation of VFI work package and } \\
\text { overall document review }\end{array}$ \\
\hline W. J. Powell & DST Engineering & $\begin{array}{l}\text { Review of document for consistency with } \\
\text { design authority }\end{array}$ \\
\hline R. R. Stickney & $\begin{array}{l}\text { TWRS Safety \& } \\
\text { Licensing }\end{array}$ & $\begin{array}{l}\text { Review and interpretation of safety } \\
\text { documentation (Noorani 1998 and } \\
\text { Pasamehmetoglu et al. 1997) }\end{array}$ \\
\hline
\end{tabular}

\section{References}

Alzheimer, J. M., 1998a, Data Acquisition Plan for Void Fraction Measurements in Tank 241-SY-101, Rev. D, TWS98.54, Pacific Northwest National Laboratory, Richland, Washington. 
Alzheimer, J. M., 1998b, the Void Fraction Instrument Data for SY-101, Riser 11-B, June 29 and July 22, 1998, Quick Look Report, TWS98.61, Pacific Northwest National Laboratory, Richland, Washington.

Carlstrom, R. F., Unresolved Safety Question Screening/Determination: "HNF-3254: Contingency Plan for Deployment of Void Fraction Instrument in Tank 241-AY102," USQ TF-98-0877, Rev. 0, Lockheed Martin Hanford Corporation, Richland, Washington.

Carothers, K. G., S. D. Estey, N. W. Kirch, L. A. Staffer, and J. W. Bailey, 1998, Tank 241-C-106 Waste Retrieval Sluicing System Process Control Plan, HNFSD-WM-PCP-013, Rev. 1, Lockheed Martin Hanford Corporation, Richland, Washington.

Erhart, M. F., 1998, Unresolved Safety Question Screening: "Deployment of the Void Fraction Instrument in Tank 241-AY-102," USQ TF-98-0-857, Rev. 0, Lockheed Martin Hanford Corporation, Richland, Washington.

Gimera, M., 1995a, Void Fraction Instrument Calibration Requirements and Procedures, WHC-SD-WM-TP-376, Rev. 0, Westinghouse Hanford Company, Richland, Washington.

Gimera, M., 1995b, Void Fraction Instrument Calibration Report, WHC-SD-WMCGA-003, Rev. 0, Westinghouse Hanford Company, Richland, Washington.

Lipnicki, J., 1997, Waste Tank Risers Available for Sampling, WHC-SD-WM-TI-170, Rev. 4, Lockheed Martin Hanford Corporation, Richland, Washington.

LMHC 1998a, "Tank 241-C-106 Waste Retrieval Technical Review Group Charter," HNF-IP-0842, Vol. 1, Section 3.18, Rev. 1, Lockheed Martin Hanford Corporation, Richland, Washington.

LMHC 1998b, Void Fraction Instrument Installation/Removal at AY-102, Work Package 2E-97-02262, Lockheed Martin Hanford Corporation, Richland, Washington.

Noorani, Y. G., 1998, Tank Waste Remediation System Basis for Interim Operations, HNF-SD-WM-BIO-001, Rev. OK, Fluor Daniel Kanford, Richland, Washington.

Pasamehmetoghu, K. O., W. L. Kubic, Jr., and P. Sadasivan, 1997, Discussion of Flammable Gas Issues for Project W-320, LA-UR-97-1330, Rev. 1A, Los Alamos National Laboratory, Los Alamos, New Mexico. 
Pearce, K. L., 1994, Void Fraction Instrument Operation and Maintenance Manual, WHC-SD-WM-OMM-011, Rev. 0, Westinghouse Hanford Company, Richland, Washington.

Wilkins, N. E., 1998, "Letter of Instruction for Void Fraction Measurements in Tank 241-SY-101," Interoffice Memo 7A120-98-002A to R. P. Tucker, July 16, Lockheed Martin Hanford Corporation, Richland, Washington. 
HNF-3254, Rev. 0

\section{APPENDIX A}

\section{Estimated Schedule and Resource Breakdown for VFI Deployment}

in Tank 241-AY-102

The following is a schedule for deployment of the void fraction instrument based on estimates made by experienced personnel. The schedule start date was arbitrarily chosen to be June 1,1999 , because the scheduling program requires a start date. Resource loading for the schedule activities is also attached. 







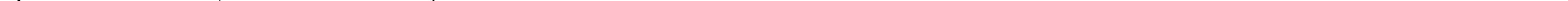




\begin{tabular}{|c|c|c|c|}
\hline $\begin{array}{l}\text { ACTNITY DESCRIPTION } \\
\text { ID }\end{array}$ & RESOURCE & $\begin{array}{l}\text { RES } \\
\text { DESC }\end{array}$ & $\begin{array}{l}\text { TOTAL } \\
\text { HOURS }\end{array}$ \\
\hline
\end{tabular}

VF1-100 Decision to deploy VFI

VFI-101 Riser Selection

CPO

VFI-102 Dome loading letter

VFl-103 Critical Lift Procedure

VFI-104 Unreviewed Safety Questions determined

VFI-105 Write WIP for transport of VFI to AY farm

VFl-106 Update VFI Deployment W/P (1998)

VFI-107 Write VFI Calibration Work Package

VFI-108 Write VFI Test Plan

VFI-109 Letter of instruction to deploy VFI

VF $\$-110$

Establish Hy-Line Engineering support Contract

VFI-200

Transport VFI to AY Farm

VFI-201

Riser prep - grounding \& bonding

VFI-202
Construct Scaffolding

\begin{tabular}{llr} 
& CPO & 5.00 \\
E07E-PS & DST ENG & 5.00 \\
& & 5.00 \\
\hline C0981 & RIGGING & 5.00 \\
& & 9.00 \\
E07E-MM & MECH ENG & 9.00 \\
& & 9.00 \\
\hline PO7E8 & & 9.00 \\
E08E1 & & 24.00 \\
M01E & & 8.00 \\
& & 8.00 \\
P07E8 & PROD CTRL & 40.00 \\
M01E & PIC & 36.00 \\
T05B & HPT & 8.00 \\
T03N1 & QC & 8.00 \\
LE12E & SAFETY & 8.00 \\
E10E-FC & FAC COG & 8.00 \\
EO8E1 & OE & 8.00 \\
& & 4.00 \\
\hline P07E8 & PROD CTRL & 80.00 \\
& & 40.00 \\
\hline & & 40.00
\end{tabular}

PNNL

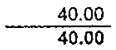

\begin{tabular}{llr} 
LEO1E-WC & PROC ENG & 9.00 \\
\cline { 3 - 3 } & & 9.00 \\
LE10E-EE & EQUIP ENG & 20.00 \\
LP03E & PROC & 20.00 \\
& & 40.00 \\
& & \\
LC09B1 & RIGGING & 24.00 \\
CR03B1 & CRANE & 8.00 \\
LR04B & OPERATOR & 8.00 \\
LTO5B & HPT & 8.00 \\
LM01E & PIC & 8.00 \\
LL07B & DRIVER & 8.00 \\
& & 64.00 \\
& & \\
LTO5B & HPT & 8.00 \\
LCO2B & ELECT & 4.00 \\
LM01E & PIC & 8.00 \\
LR04B & OPERATOR & 24.00 \\
& & 44.00 \\
& & \\
LC09B1 & RIGGING & 24.00 \\
LT05B & HPT & 8.00 \\
LLO7B & DRIVER & 8.00 \\
LM01E & PIC & 8.00 \\
LR048 & OPERATOR & .8 .00 \\
\hline & & 56.00
\end{tabular}




ACTIVTY DESCRIPTION RES TOTAL

$1 \mathrm{D}$ RESOURCE DESC HOURS

VF $\{-203$

$\begin{array}{ll}\text { Insti VFI cntrl console, pwr dist skid, whr enc } & \text { CRO3B1 } \\ \text { LCO9B1 } \\ \text { LR04B } \\ \text { LCO2B } \\ \text { LMO1E } \\ \text { LLO7B } \\ \text { LTO5B }\end{array}$

VFI-204 Install ball vaive and spray wasiner

\section{LMO1E \\ LTO5B \\ I.R048 \\ LTO6B \\ LCOSB I \\ CR03B1}

VF!-205 Install portable camera

VFI-206 Calibrate VFI (before install)

VFI-207 Install VFI, operate \& remove

VFl-208

VFI-209
Remove Portable Camera

Remove spray washer $\&$ ball vaive \& close riser
LLOTB

\section{CRANE \\ RIGGING \\ OPERATOR \\ ELECT \\ PIC \\ DRIVER \\ HPT}

PIC

HPT

OPERATOR

$\mathrm{IH}$

RIGGING

CRANE

DRIVER

LR04B

LTO5B

LTO6B

LCO2B

LMO1E

LTO3N1
LTO7B
LRO4B
LMO1E
LCO88
LETOE-EE

LROAB

LTO5B

LT06B

LCO9B1

CRO3B1

LMO1E

LE1OE-EE

LLO7B

\section{LR04B \\ LT068 \\ LMOTE \\ LCO2B \\ LTO5B}

L.ROAB

LTO5B

LT068

LCO2B

LCOSB 1

CRO3B1

LLOTB

LMOTE

\begin{tabular}{lr} 
OPERATOR & 32.00 \\
HPT & 24.00 \\
IH & 8.00 \\
ELECT & 8.00 \\
FIC & 8.00 \\
\hline
\end{tabular}

QC INSTR TECH OPERATOR

PIC

FITTER

EQUIP ENG

OPERATOR

HPT

IH

RIGGING

CRANE

PIC

EQUIP ENG

DRIVER

8.00

8.00

8.00

8.00

800

16.00

56.00

80.00

48.00

16.00

64.00

32.00

16.00

16.00

16.00

\begin{tabular}{lr} 
OPERATOR & 32.00 \\
I\&H & 8.00 \\
PIC & 8.00 \\
ELECT & 8.00 \\
HPT & 24.00 \\
\hline
\end{tabular}

OPERATOR

24.00

HPT

$\mathrm{IH}$

ELECT

RIGGING

CRANE

DRIVER

PIC

24.00

8.00

8.00

24.00

8.00

8.00

8.00 
Void : action Deployment

PRIMAVERA PROJECT PLANNER

-..-Project Schedule...
John Conner 373-2741

START DATE 01JUN99

FIN DATE 07JUL 99 44:18

Resource Control - Detailed 8y Activity

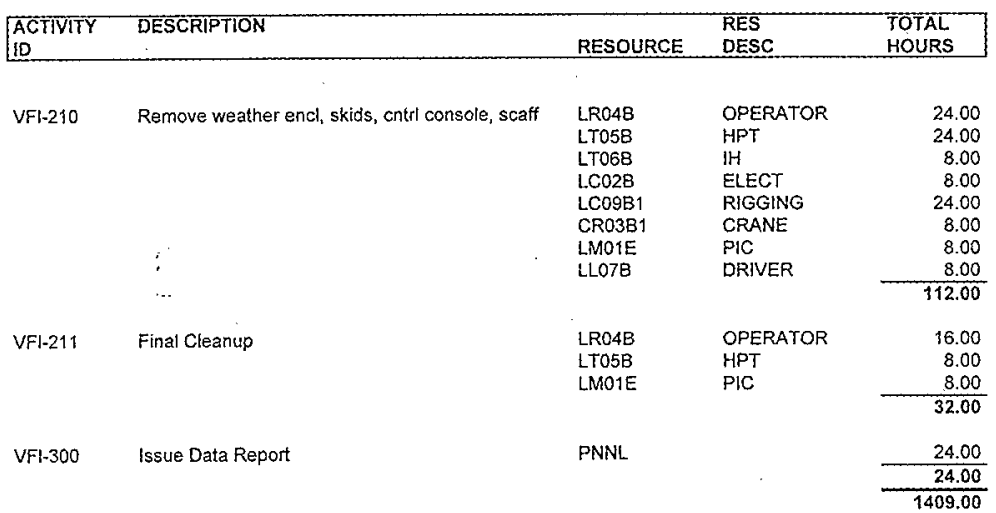




\begin{tabular}{|c|c|c|c|c|c|}
\hline \multicolumn{6}{|c|}{ DISTRIBUTION SHEET } \\
\hline \multirow[b]{2}{*}{ Distribution } & \multirow{2}{*}{\multicolumn{3}{|c|}{ Process Control }} & \multicolumn{2}{|l|}{ Page 1 of 1} \\
\hline & & & & \multicolumn{2}{|c|}{ Date $\quad 08 / 28 / 98$} \\
\hline \multirow{2}{*}{\multicolumn{4}{|c|}{$\begin{array}{l}\text { Project Tit\}e/Work Order } \\
\text { HNF-3254, Rev. 0, "Contingency P Ian for Deployment of the Void } \\
\text { Fraction Instrument in Tank 241-AY-102" }\end{array}$}} & \multicolumn{2}{|c|}{ EDT No. EOT-622465 } \\
\hline & & & & \multicolumn{2}{|c|}{ ECN No. N/A } \\
\hline Name & MSIN & $\begin{array}{c}\text { Text } \\
\text { with } \\
\text { All } \\
\text { Attach }\end{array}$ & $\begin{array}{l}\text { Text } \\
\text { Oniy }\end{array}$ & $\begin{array}{l}\text { Attach./ } \\
\text { Appendix } \\
\text { Only }\end{array}$ & $\begin{array}{c}\text { EDT/ECN } \\
\text { Only }\end{array}$ \\
\hline
\end{tabular}

ONSITE

DE\&S Hanford, InC.

R. G. Stickney

R1-49 X

Lockheed Martin Hanford. Corp.
D. G. Baide
W. D. Bancroft
K. G. Carothers
J. M. Conner
M. F. Erhart
G. N. Hanson
T. J. Kelley
N. W. Kirch
W. 3. Powell
R. L. Powers
R. S. Rodriquez
G. R. Tardiff
T.C.S.R.C.

S5-05

S5-07

R2- 11

R2-12

R1-56

S5-07

$\$ 5-07$

R2-11

$55-13$

$55-13$

$50-09$

S5-05

R1-10

Lockheed Martin Services. Inc.

Central Files

BI-07 $\quad X$

Numatec Hanford Corporation

3. W. Bailey

$\$ 2-48 \quad x$

3. W. Lentsch

S2-48

Pacific Northwest National Laboratory

3. M. Aizheimer

c. W. Stewart

$k 5-22 \quad x$

$k 7-15 \quad x$

Weirich and Associates

J. D. Thorne

So-09 $\quad x$ DoElRL Reoding Room

Hiss $x$ 